

\title{
ANALISIS SIKAP KONSUMEN PADA PEMBELIAN BERAS DI KOTA SALATIGA
}

\author{
(Analysis of Consumer Attitudes on Purchasing the Rice in Salatiga City) \\ Farah Kamila, Eddy Prasetyo dan Wiludjeng Roessali \\ Program Studi S1 Agribisnis Fakultas Peternakan dan Pertanian Universitas Diponegoro \\ Email : farahkamila30@gmail.com
}

Diterima 21 Juli 2018, disetujui 19 Mei 2019

\begin{abstract}
ABSTRAK
Tujuan penelitian adalah untuk menganalisis sikap konsumen terhadap atribut yang paling mempengaruhi pembelian beras dan menganalisis faktor-faktor yang mempengaruhi keputusan pembelian beras organik dan non organik di Kota Salatiga. Penelitian dilaksanakan pada bulan Januari 2018 di Kelurahan Kutowinangun Lor, Kelurahan Kalibening, Kelurahan Tegalrejo dan Kelurahan Cebongan, Kota Salatiga. Metode survey digunakan untuk koleksi data. Pengambilan sampel menggunakan metode multistage clustersampling. Penentuan jumlah responden menggunakan metode quota sampling dengan responden sebanyak 100 orang. Analisis data menggunakan model multiatribut fishbein dan regresi logistik biner. Hasil penelitian menunjukkan bahwa responden beras di Kota Salatiga lebih menyukai beras non organik. Atribut beras yang paling mempengaruhi sikap konsumen terhadap pembelian beras organik dan non organik adalah harga. Secara serempak variabel jenis kelamin, umur, pendapatan, jumlah anggota keluarga, ketersediaan beras non organik dan harga beras non organik berpengaruh signifikan terhadap keputusan pembelian beras. Secara parsial, variabel pendapatan dan ketersediaan beras non organik berpengaruh signifikan terhadap keputusan pembelian beras, sedangkan variabel jenis kelamin, umur, jumlah anggota keluarga dan harga beras non organik tidak berpengaruh terhadap keputusan pembelian beras di Kota Salatiga.
\end{abstract}

Kata Kunci : beras, fishbein, keputusan pembelian, logit, sikap

\begin{abstract}
The aim of this research was to analyze the consumer's attitude toward the most influencing attribute of purchasing the organic and non-organic rice also to analyze the factors that influence the consumer's decision to buy it in Salatiga. The research was held in January 2018 in Kutowinangun Lor, Kalibening, Tegalrejo and Cebongan. The survey method was used for data collection. Sampling using a multistage cluster sampling method. Determination of respondents using quota sampling method with as many as 100 respondents. Data analysis used Fishbein Multiattribute Model and Binary Logistic Regression. The result showed that rice respondents in Salatiga preferred to buy non-organic rice. The attribute of rice that most influence consumers attitude towards to buy organic rice and non-organic rice is the price. Simultaneously the variable of gender, age, income, the number of family members, availability of non-organic rice and price of non-organic rice have a significant effect on the decision to buy rice. The variable of income and availability of non-organic rice have a significant effect on the rice purchasing decision, while the variable of gender, age, the number of family members and price of nonorganic rice has no influence the decision to buy the rice in Salatiga.
\end{abstract}

Keywords : attitude, buying decision, fishbein, logit, rice 


\section{PENDAHULUAN}

Tanaman pangan merupakan penyokong terbesar kedua dari sub sektor pertanian terhadap Produk Domestik Bruto (PDB) sektor pertanian. PDB untuk tanaman pangan dalam sektor pertanian di Indonesia atas Dasar Harga Konstan 2010 menyumbang 26,14\% dari total PDB sektor pertanian (Statistik Pertanian, 2016). Salah satu jenis tanaman pangan adalah padi, yang kemudian diolah menjadi beras dan dikonsumsi dalam bentuk nasi. Menurut Pusat Data dan Sistem Informasi Pertanian (PUSDATIN, 2013), komoditas utama tanaman pangan dalam hal ini padi (beras) merupakan bahan makanan utama masyarakat Indonesia yang mencapai 252,17 juta orang dengan laju pertumbuhan sebesar $1,21 \%$ dan tingkat konsumsi beras mencapai 132,98 kg/kapita/tahun.

Beras yang dikonsumsi oleh masyarakat Indonesia terdiri atas dua jenis yaitu beras organik dan beras non organik. Beras organik merupakan beras yang dihasilkan dari kegiatan budidaya padi organik dan tidak menggunakan pupuk dan pestisida kimia selama produksi (Setiawan et al., 2016). Beras organik masih dianggap sebagian besar orang sebagai beras yang eksklusif, dalam arti bahwa beras organik tidak dijual dan dipasarkan di sembarang tempat. Beras organik dikemas dalam plastik berlebel dan dijual dengan harga yang relatif lebih mahal dari beras non organik. Hal tersebut menyebabkan konsumen dari jenis beras ini berasal dari kalangan atas. Meski begitu tidak sedikit pula orang yang memilih untuk mengkonsumsi beras organik, karena masyarakat mulai sadar dampak negatif yang ditimbulkan oleh pemakaian bahan kimia sintetis dalam pertanian khususnya dalam produksi beras non organik. Untuk melihat perbedaan sikap konsumen terhadap konsumsi beras organik dan non organik, diperlukan suatu cara untuk mengetahui faktor-faktor apa saja yang mempengaruhi keputusan pembelian beras oleh konsumen. Keputusan pembelian salah satu jenis beras tersebut merupakan bagian dari unsur yang melekat pada setiap individu dan akan mempengaruhi perilaku konsumen, dimana konsumen dapat menentukan akan mencari, membeli dan menentukan produk pilihannya (Budiyanto, 1994).

Keputusan pembelian beras organik di Kota Bogor dipengaruhi oleh enam variabel yaitu kualitas, promosi, harga, pengaruh teman dan keluarga (Rusma et al., 2011). Faktor-faktor yang mempengaruhi preferensi konsumen terhadap beras organik di Kota Yogyakarta adalah harga beras organik, tingkat pendidikan isteri, pendapatan perkapita rumahtangga dan jumlah anggota keluarga (Windani dan Mulyo, 2009). Penelitian ini bertujuan untuk menganalisis sikap konsumen terhadap atribut produk yang paling mempengaruhi pembelian beras organik dan beras non organik dan menganalisis faktor-faktor yang mempengaruhi keputusan pembelian beras organik dan non organik di Kota Salatiga.

\section{METODE PENELITIAN}

Penelitian dilaksanakan pada bulan Januari 2018. Lokasi penelitian di Kota Salatiga meliputi Kelurahan Kutowinangun Lor, Kelurahan Kalibening, Kelurahan Tegalrejo dan Kelurahan Cebongan. Metode survey digunakan untuk pengumpulan data. Metode pengambilan sampel secara multistage cluster sampling. Penentuan responden selanjutnya dilakukan dengan metode quota sampling dengan jumlah responden adalah 100 orang.

Data yang digunakan dalam penelitian ini terdiri dari data primer dan data sekunder. Data primer diperoleh dari wawancara langsung kepada konsumen beras dengan menggunakan kuesioner, sedangkan data sekunder berupa literature, jurnal atau sumber lainnya yang berhubungan dengan penelitian ini.

Analisis data yang digunakan dalam penelitian ini adalah model multiatribut fishbein dan regresi logistik biner (logit) dengan alat bantu aplikasi SPSS 22 (Statistic Package for Social Science) dan Microsoft 
Excel untuk mentabulasi data. Model Multiatribut Fishbein digunakan untuk mengukur sikap terhadap atribut produk dengan keputusan akhir untuk membeli atau tidak. Elemen utama dari model ini yaitu kekuatan kepercayaan/ keyakinan (belief strenght), dimana kemungkinan diyakini dari hubungan antara suatu objek dengan ciri-ciri yang relevan dan evaluasi (belief/evaluation), yaitu mencerminkan seberapa baik konsumen menilai suatu ciri (Anggiasari et al., 2019).

Secara simbolis, formulasi model Fishbein menurut Engel et al. (1994) dapat dirumuskan:

$$
A o=\sum_{i=1}^{n} b i . e i
$$

Keterangan:

Ao $=$ Perilaku terhadap keputusan pembelian

$\mathrm{b}_{\mathrm{i}}=$ Tingkat kepercayaan bahwa objek memiliki atributi (Skor)

$\mathrm{e}_{\mathrm{i}} \quad=$ Evaluasi kepentingan terhadap atributi (Skor)

$\mathrm{n} \quad=$ Jumlah atribut yang dimiliki oleh objek

Sikap konsumen (Ao) terhadap produk dengan membandingkannya menggunakan skala interval, rumus yang digunakan dapat dilihat pada persamaan 2 sebagai berikut:

Skala interval $=\frac{m-n}{b}$

Keterangan:

$\mathrm{m}=$ Skor tertinggi yang mungkin terjadi

$\mathrm{n} \quad=$ Skor terendah yang mungkin terjadi

$\mathrm{b}=$ Jumlah skala penilaian yang terbentuk

Besarnya range untuk tingkat kepercayaan dan tingkat evaluasi (kepentingan) dapat dilihat pada Tabel 1.

Skala interval $=\frac{5-1}{5}=0,8$

Hasil penilaian sikap responden terhadap atribut beras organik dan beras non organik $\left(\mathrm{e}_{\mathrm{i}} \cdot \mathrm{b}_{\mathrm{i}}\right)$ diinterpretasikan ke dalam 5 kategori, yaitu sangat negatif, negatif, netral, positif dan sangat positif. Besarnya range untuk kategori sikap dapat dilihat pada Tabel 2 .

Skala interval $=\frac{(5 \times 5)-(1 \times 1)}{5}=4,8$

Analisis Regresi Logistik Biner digunakan untuk mengetahui faktor-faktor yang mempengaruhi keputusan pembelian beras organik dan beras non organik di Kota

Tabel 1. Kategori Tingkat Kepercayaan dan Tingkat Kepentingan Konsumen

\begin{tabular}{lcll}
\hline \multicolumn{1}{c}{ Tingkat Kepercayaan } & Nilai & \multicolumn{1}{c}{ Tingkat Kepentingan } & Nilai \\
\hline Sangat Tidak Setuju & $1.0 \leq \mathrm{b}_{\mathrm{i}} \leq 1.8$ & Sangat Tidak Penting & $1.0 \leq \mathrm{e}_{\mathrm{i}} \leq 1.8$ \\
Tidak Setuju & $1.8<\mathrm{b}_{\mathrm{i}} \leq 2.6$ & Tidak Penting & $1.8<\mathrm{e}_{\mathrm{i}} \leq 2.6$ \\
Netral & $2.6<\mathrm{b}_{\mathrm{i}} \leq 3.4$ & Netral & $2.6<\mathrm{e}_{\mathrm{i}} \leq 3.4$ \\
Setuju & $3.4<\mathrm{b}_{\mathrm{i}} \leq 4.2$ & Penting & $3.4<\mathrm{e}_{\mathrm{i}} \leq 4.2$ \\
Sangat Setuju & $4.2<\mathrm{b}_{\mathrm{i}} \leq 5.0$ & Sangat Penting & $4.2<\mathrm{e}_{\mathrm{i}} \leq 5.0$ \\
\hline
\end{tabular}

Tabel 2. Kategori Nilai Sikap terhadap Atribut Beras

\begin{tabular}{clr}
\hline Skala & \multicolumn{1}{c}{ Nilai Sikap Atribut } & Nilai \\
\hline 1 & Sangat Negatif & $1.0 \leq \mathrm{A}_{0} \leq 5.8$ \\
2 & Negatif & $5.8<\mathrm{A}_{0} \leq 10.6$ \\
3 & Netral & $10.6<\mathrm{A}_{0} \leq 15.4$ \\
4 & Positif & $15.4<\mathrm{A}_{0} \leq 20.2$ \\
5 & Sangat Positif & $20.2<\mathrm{A}_{0} \leq 25.0$ \\
\hline
\end{tabular}


Salatiga. Formulasi model Regresi Logistik Biner dapat dirumuskan pada persamaan 3 sebagai berikut (Teme, 2006):

$$
\begin{aligned}
& Y=\ln =\beta_{0}+\beta_{1} X_{1}+\beta_{2} X_{2}+\beta_{3} X_{3}+\beta_{4} X_{4} \\
& +\beta_{5} X_{5}+\beta_{6} X_{6}+e
\end{aligned}
$$

Keterangan :

$\mathrm{Y}=1$ : Pembelian beras organik (skor)

$\mathrm{Y}=0$ : Pembelian beras non organik (skor)

$\beta_{0}:$ Konstanta

$\mathrm{X}_{1}$ : Jenis Kelamin (skor)

$\mathrm{X}_{2}$ : Umur (skor)

$\mathrm{X}_{3}$ : Pendapatan (skor)

$\mathrm{X}_{4}$ : Jumlah Anggota Keluarga (skor)

$\mathrm{X}_{5}$ : Ketersediaan Beras Non Organik (skor)

$\mathrm{X}_{6}$ : Harga Beras Non Organik (skor)

e : Standar error

Adapun hipotesis statistik yaitu:

$\mathrm{H}_{0}: \beta=0$ berarti tidak ada pengaruh $\mathrm{X}$ terhadap Y

$\mathrm{H}_{1}: \beta \neq 0$ berarti ada pengaruh $\mathrm{X}$ terhadap $\mathrm{Y}$

Uji Hosmer and Lemeshow test (Goodness of fit) digunakan untuk mengetahui apakah model regresi yang diajukan diterima atau tidak. Jika hasil uji Hosmer and Lemeshow test memiliki nilai probabilitas lebih besar dari 0,05, maka hipotesis nol tidak dapat ditolak. Sehingga Goodness of fit model baik dan dapat diterima karena dapat memprediksi nilai observasinya. Uji Pseudo $R$ Square digunakan untuk mengetahui seberapa besar variabel bebas mampu menjelaskan variabel terikat. Hasil uji Pseudo $R$ Square dapat dilihat pada nilai Nagelkerke $R$ Square. Nilai Nagelkerke $R$ Square $\left(R^{2}\right)$ menunjukkan besarnya kemampuan variabel bebas dalam menjelaskan variasi yang terjadi pada variabel terikat. Uji Wald atau uji parsial digunakan untuk mengetahui pengaruh masing-masing variabel bebas terhadap variabel terikat. Variabel dinyatakan signifikan apabila nilai $\mathrm{P}$ value (sig) $<0,05$ (Ghozali, 2005).
Uji Omnibus test atau uji simultan (serempak) digunakan untuk mengetahui pengaruh semua variabel bebas sebagai penjelas variabel terikat di dalam model secara besama-sama (overall). Jika nilai ChiSquare model $>$ Chi-Square tabel maka $\mathrm{H}_{0}$ ditolak, artinya variabel bebas secara serempak berpengaruh signifikan terhadap variabel terikat (Gujarati, 2004).

\section{HASIL DAN PEMBAHASAN}

\section{Identitas Responden}

Berdasarkan hasil penelitian, dapat diketahui bahwa persentase responden perempuan sebanyak 86 orang $(86 \%)$ dan laki-laki sebanyak 14 orang (14\%). Pengelompokan usia dalam penelitian ini terbagi dalam empat kategori usia, yaitu 2130 tahun, 31-40 tahun, 41-50 tahun dan usia diatas 51 tahun. Mayoritas responden dalam penelitian berada pada rentang usia 41-50 tahun $(33 \%)$. Sebanyak 33 responden (33\%) telah menyelesaikan pendidikan sampai tingkat SMA. Mayoritas pendapatan responden beras atau sebanyak 26 orang $(26 \%)$ berada pada rentang Rp 3.000.000 Rp 4.500.000, dan sebesar $46 \%$ responden memiliki jumlah anggota keluarga $3-4$ orang.

\section{Sikap Konsumen Terhadap Atribut Beras}

Berdasarkan Model Multiatribut Fishbein, dimensi pertama dari variabel sikap konsumen adalah evaluasi tingkat kepercayaan terhadap 4 atribut beras. Variabel ini menggambarkan bagaimana konsumen menilai tingkat kepercayaan dari 4 atribut beras, yaitu harga, kualitas, merek dan ketersediaan. Tabel 3 menunjukkan nilai rataan kepercayaan konsumen terhadap keempat atribut beras organik dan beras non organik.

Hasil penelitian Tabel 3 menunjukkan bahwa kepercayaan konsumen terhadap atribut rasa beras organik merupakan yang tertinggi, dengan nilai rata-rata 2,50. Nilai tersebut masih tergolong rendah dalam dimensi kepercayaan di dalam model atribut 
Tabel 3. Kepercayaan Konsumen $\left(b_{i}\right)$ terhadap Atribut Produk Beras Organik dan Non Organik.

\begin{tabular}{lclcl}
\hline \multirow{2}{*}{ Atribut } & \multicolumn{2}{c}{ Beras Organik } & \multicolumn{2}{c}{ Beras Non Organik } \\
\cline { 2 - 5 } & $\mathrm{b}_{\mathrm{i}}$ & \multicolumn{1}{c}{ Kategori } & $\mathrm{b}_{\mathrm{i}}$ & \multicolumn{1}{c}{ Kategori } \\
\hline Harga & 1,59 & Sangat Tidak Setuju & 4,14 & Sangat Setuju \\
Rasa & 2,50 & Tidak Setuju & 3,68 & Setuju \\
Merk & 1,90 & Tidak Setuju & 2,75 & Tidak Setuju \\
Ketersediaan & 1,54 & Sangat Tidak Setuju & 3,91 & Setuju \\
\hline
\end{tabular}

Tabel 4. Kepentingan Konsumen $\left(\mathrm{e}_{\mathrm{i}}\right)$ terhadap Atribut Produk Beras Organik dan Non Organik.

\begin{tabular}{lclcl}
\hline \multirow{2}{*}{ Atribut } & \multicolumn{2}{c}{ Beras Organik } & \multicolumn{2}{c}{ Beras Non Organik } \\
\cline { 2 - 5 } & $\mathrm{e}_{\mathrm{i}}$ & \multicolumn{1}{c}{ Kategori } & $\mathrm{e}_{\mathrm{i}}$ & Kategori \\
\cline { 2 - 5 } Harga & 4,16 & Penting & 3,40 & Penting \\
Rasa & 2,26 & Tidak penting & 3,48 & Penting \\
Merk & 1,68 & Sangat tidak penting & 2,56 & Tidak penting \\
Ketersediaan & 1,57 & Sangat tidak penting & 3,42 & Penting \\
\hline
\end{tabular}

fishbein. Artinya konsumen tidak setuju bahwa beras organik memiliki rasa yang lebih baik dari beras non organik. Konsumen beras di Kota Salatiga menganggap bahwa rasa dari beras organik tidak berbeda jauh dengan beras non organik. Sedangkan kepercayaan konsumen terhadap atribut ketersediaan beras organik merupakan yang terendah, dengan rata-rata 1,54. Hal tersebut menunjukkan bahwa konsumen sangat tidak setuju bahwa beras organik mudah dibeli dimana saja. Artinya konsumen menganggap bahwa beras organik hanya tersedia di pasar modern, bukan di warung sekitar rumah atau pasar tradisional. Hal itu sesuai dengan pendapat Sumarwan et al. (2013) yang menyatakan bahwa tempat pembelian beras organik juga menjadi salah satu faktor yang berpengaruh besar dalam proses pembelian produk organik.

Tabel 3 menunjukkan bahwa kepercayaan konsumen terhadap atribut harga beras non organik merupakan yang tertinggi, dengan nilai rata-rata 4,14. Artinya konsumen beras di Kota Salatiga sangat setuju bahwa harga beras non organik lebih murah dan terjangkau dibanding beras organik. Harga beras organik yang tinggi dapat disebabkan karena tingginya manfaat dari beras tersebut. Hal itu sesuai dengan pendapat Sulistyana et al. (2014) yang menyatakan bahwa beras organik sangat baik untuk kesehatan karena bebas dari bahan kimia yang berbahaya. Kepercayaan konsumen terhadap atribut merek beras non organik merupakan yang terendah, dengan rata-rata 2,75. Artinya konsumen tidak setuju bahwa mereka membeli beras non oganik dengan melihat mereknya terlebih dahulu.

Dimensi kedua dari variabel sikap konsumen adalah evaluasi tingkat kepentingan terhadap 4 atribut beras. Variabel ini menggambarkan bagaimana konsumen menilai tingkat kepentingan dari 4 atribut beras, yaitu harga, rasa, merek dan ketersediaan. Tabel 4 menunjukkan nilai rataan kepentingan konsumen terhadap keempat atribut beras organik dan beras non organik.

Tabel 4 menunjukkan bahwa harga memiliki nilai rataan tertinggi dalam kategori kepentingan (evaluasi) konsumen terhadap beras organik, yaitu sebesar 4,16. Hal tersebut menunjukkan bahwa harga dari beras organik merupakan pertimbangan yang penting bagi konsumen beras di Kota Salatiga dalam 
Tabel 5. Sikap Konsumen (Ao) Beras Organik dan Beras Non Organik

\begin{tabular}{|c|c|c|c|c|c|c|}
\hline \multirow[t]{2}{*}{ Atribut Beras } & \multicolumn{3}{|c|}{ Beras Organik } & \multicolumn{3}{|c|}{ Beras Non Organik } \\
\hline & $(\mathrm{ei})$ & (bi) & (Ao) & (ei) & (bi) & (Ao) \\
\hline$\overline{\text { Harga }}$ & 4,16 & 1,59 & 6,61 & 3,4 & 4,14 & 14,08 \\
\hline Rasa & 2,26 & 2,5 & 5,65 & 3,48 & 3,68 & 12,81 \\
\hline Merk & 1,68 & 1,9 & 3,19 & 2,56 & 2,75 & 7,04 \\
\hline Ketersediaan & 1,57 & 1,54 & 2,42 & 3,43 & 3,91 & 13,41 \\
\hline$\overline{\sum(\mathrm{bi}, \mathrm{ei})}$ & & & 17,87 & & & 47,33 \\
\hline
\end{tabular}

membeli beras organik, mengingat harga dari beras organik cukup mahal. Sedangkan atribut ketersedian memiliki rataan terendah yaitu 1,57. Hal tersebut menunjukkan bahwa ketersediaan dari beras organik tidak memiliki peran penting dalam keputusan pembelian konsumen beras di Kota Salatiga.

Tabel 4 menunjukkan bahwa rasa memiliki nilai rataan tertinggi dalam kategori kepentingan (evaluasi) konsumen terhadap beras non organik, yaitu sebesar 3,48. Hal tersebut menunjukkan bahwa rasa dari beras non organik merupakan pertimbangan yang penting bagi konsumen beras di Kota Salatiga dalam membeli beras non organik. Sedangkan atribut merek memiliki rataan terendah yaitu 2,56 . Hal tersebut menunjukkan bahwa merek tidak dapat menentukan pilihan konsumen dalam keputusan pembelian beras non organik.

Penilaian sikap konsumen terhadap atribut-atribut beras organik dan non organik dapat dihitung berdasarkan nilai rataan dari kepercayaan atribut $\left(b_{i}\right)$ dan evaluasi kepentingan $\left(\mathrm{e}_{\mathrm{i}}\right)$, yaitu dengan mengalikan kedua variabel. Apabila nilai sikap untuk masing-masing atribut dijumlahkan maka akan diperoleh nilai sikap secara keseluruhan untuk beras organik dan beras non organik (Ao). Hasil analisis sikap konsumen $\left(\mathrm{b}_{\mathrm{i}} \cdot \mathrm{e}_{\mathrm{i}}\right)$ dan total nilai sikap (Ao). Sikap konsumen beras organik dan non organik dapat dilihat pada Tabel 5.

Atribut harga untuk beras organik mempunyai nilai sikap sebesar 6,61 sedangkan untuk atribut harga pada beras non organik mempunyai nilai sikap sebesar 14,08.
Konsumen setuju harga dari beras non organik lebih murah dibanding beras organik. Berdasarkan aspek harga, konsumen pada penelitian ini mempunyai sikap yang lebih tinggi terhadap beras non organik daripada beras organik.

Atribut rasa untuk beras organik mempunyai nilai sikap sebesar 5,65 sedangkan untuk atribut rasa pada beras non organik mempunyai nilai sikap sebesar 12,81 . Hal tersebut menunjukkan bahwa konsumen pada penelitian ini menganggap bahwa beras non organik lebih enak dari beras non organik.

Atribut merek untuk beras organik mempunyai nilai sikap sebesar 3,19 sedangkan untuk atribut merek pada beras non organik memiliki nilai sikap sebesar 7,04, Merek dari beras non organik dinilai konsumen lebih diketahui dan lebih familiar dari beras organik

Atribut ketersediaan untuk beras organik memiliki nilai sikap sebesar 2,42 sedangkan untuk atribut ketersediaan pada beras non organik memiliki nilai sikap sebesar 13,37. Hal tersebut menunjukkan bahwa ketersediaan beras non lebih banyak dibanding beras organik, karena dapat dibeli di warung sekitar rumah,

Berdasarkan hasil nilai sikap keseluruhan konsumen dapat diketahui bahwa nilai sikap keseluruhan (Ao) untuk beras organik sebesar 17,87 sedangkan nilai sikap keseluruhan (Ao) untuk beras non organik sebesar 47,29. Hal tersebut menunjukan bahwa secara keseluruhan sikap konsumen lebih positif pada beras non organik daripada beras organik. Putra et al. (2016) menyimpulkan 
bahwa sikap positif memiliki pengertian semakin kuat sikap membeli dan semakin tinggi niat untuk membeli. Pada penelitian ini konsumen di Kota Salatiga menyikapi beras non organik masih dianggap lebih baik karena harganya lebih murah, rasanya enak, mereknya lebih dikenal dan dapat dibeli dimana saja.

\section{Faktor-Faktor yang Mempengaruhi Keputusan Pembelian}

Berdasarkan hasil penelitian dapat diketahui bahwa hasil uji Hosmer and Lemeshow test menunjukkan nilai Chi-square Hosmer and Lemeshow hitung sebesar 1,692< 15,51 (nilai Chi-Square tabel untuk df 8) dan nilai signifikansi sebesar $0,989>0,05$ sehingga $\mathrm{H}_{0}$ diterima dan $\mathrm{H}_{1}$ ditolak, artinya uji model regresi yang diajukan dapat diterima dan pengujian hipotesis dapat dilakukan, Pseudo $R$ Square pada nilai Nagelkerke $R$ Square diguna sebesar 0,773, Hal tersebut menunjukkan bahwa variabel bebas mampu menjelaskan variabel terikat sebesar 0,773 atau $77,3 \%$ dan sisanya merupakan faktor lain di luar model yang mampu menjelaskan variabel terikat, Uji Omnibus test atau uji simultan (serempak) digunakan untuk mengetahui pengaruh semua variabel bebas sebagai penjelas variabel terikat di dalam model secara besama-sama (overall), Hasil uji simultan disajikan pada Tabel 6.

Tabel 6. Hasil Uji Simultan Omnimbus Test of Model Cefficients

\begin{tabular}{cccc}
\hline & Chi-Square & df & Sig, \\
\hline Step 1Step & 48,864 & 6 & 0,000 \\
Block & 48,864 & 6 & 0,000 \\
Model & 48,864 & 6 & 0,000 \\
\hline
\end{tabular}

Berdasarkan Tabel 6 dapat diketahui bahwa hasil uji Omnibus test menunjukkan nilai Chi-Square sebesar 48,864 > Chi-Square tabel pada df 6 sebesar 12,59 atau dengan probabilitas signifikansi sebesar $0,000<0,05$ sehingga $\mathrm{H}_{0}$ ditolak dan $\mathrm{H}_{1}$ diterima, artinya penambahan variabel bebas dapat memberikan pengaruh yang nyata terhadap model, atau variabel bebas secara serempak merupakan penjelas yang signifikan. Gujarati (2004) menyatakan bahwa jika nilai ChiSquare model $>$ Chi-Square tabel maka $\mathrm{H}_{0}$ ditolak, artinya variabel bebas secara serempak berpengaruh signifikan terhadap variabel terikat.

Uji parsial digunakan untuk mengetahui pengaruh variabel bebas secara parsial terhadap variabel terikat. Uji parsial dalam regresi logistik diuji menggunakan uji Wald. Uji parsial disajikan pada Tabel 7.

Tabel 7. Uji Parsial dalam Variables in The Equation

\begin{tabular}{lccc}
\hline \multicolumn{1}{c}{ Variabel } & $\begin{array}{r}\text { Coefficient } \\
\text { (B) }\end{array}$ & $\begin{array}{c}\text { Wald } \\
\text { (Sig, })\end{array}$ & $\begin{array}{c}\text { Odds Ratio } \\
\text { (Exp,B) }\end{array}$ \\
\hline Jenis Kelamin & $-0,198$ & 0,881 & 0,820 \\
Usia & 0,626 & 0,329 & 1,871 \\
Pendapatan & 1,828 & 0,022 & 6,222 \\
Jumlah & & & \\
Anggota & 0,241 & 0,717 & 1,272 \\
$\begin{array}{l}\text { Keluarga } \\
\text { Ketersediaan }\end{array}$ & & & \\
$\begin{array}{l}\text { Beras Non } \\
\text { Organik }\end{array}$ & $-1,920$ & 0,025 & 0,147 \\
$\begin{array}{l}\text { Harga Beras } \\
\text { Non Organik }\end{array}$ & 1,203 & 0,307 & 0,307 \\
Constant & $-2,653$ & 0,654 & 0,654 \\
\hline
\end{tabular}

Berdasarkan Tabel 7 dapat diketahui bahwa hasil uji Wald menunjukkan nilai signifikansi untuk variabel jenis kelamin sebesar $0,881>0,05$ sehingga $\mathrm{H}_{0}$ diterima dan $\mathrm{H}_{1}$ ditolak, artinya variabel jenis kelamin secara parsial tidak memberi pengaruh yang signifikan terhadap keputusan pembelian beras non organik di Kota Salatiga. Hal ini sesuai dengan pendapat Winawan dan Yasa (2014) yang menyatakan bahwa perbedaan jenis kelamin antara perempuan dan laki-laki tidak mempengaruhi keputusan pembelian, baik pembelian terencana maupun tidak terencana. 
Nilai signifikansi untuk variabel usia sebesar $0,329>0,05$ sehingga $\mathrm{H}_{0}$ diterima dan $\mathrm{H}_{1}$ ditolak, artinya variabel usia secara parsial tidak memberi pengaruh yang signifikan terhadap keputusan pembelian beras non organik di Kota Salatiga. Hal tersebut sesuai dengan pernyataan Lestari (2018) yang berpendapat bahwa faktor kepribadian (usia) tidak berpengaruh terhadap perilaku dan minat beli seseorang terhadap suatu produk.

Nilai signifikansi untuk variabel pendapatan sebesar $0,022<0,05$, sehingga $\mathrm{H}_{0}$ ditolak dan $\mathrm{H}_{1}$ diterima, artinya variabel pendapatan secara parsial memberi pengaruh yang signifikan terhadap keputusan pembelian beras non organik di Kota Salatiga. Hal tersebut sesuai dengan pendapat Setiadi (2003) yang menyatakan bahwa daya beli yang terdapat dalam suatu perekonomian bergantung pada tingkat dan distribusi yang berbeda-beda. Pendapatan dapat sangat mempengaruhi keputusan pembelian konsumen. Apabila pendapatan meningkat, maka kemampuan rumah tangga untuk membeli aneka kebutuhan semakin besar.

Nilai signifikansi untuk variabel jumlah anggota keluarga sebesar 0,717 $>0,05$ sehingga $\mathrm{H}_{0}$ diterima dan $\mathrm{H}_{1}$ ditolak, artinya variabel jumlah anggota keluarga secara parsial tidak memberi pengaruh terhadap keputusan pembelian beras non organik di Kota Salatiga. Hal tersebut tidak sesuai dengan pendapat Sabran (2008) yang menyatakan bahwa anggota keluarga dapat mempengaruhi keputusan pembelian konsumsi individu karena keluarga dapat membentuk lingkungan bagi individu untuk memperoleh nilai dan membentuk kepribadian.

Nilai signifikansi untuk variabel ketersediaan beras non organik sebesar $0,0254<0,05$ sehingga $\mathrm{H}_{0}$ ditolak dan $\mathrm{H}_{1}$ diterima, artinya variabel ketersediaan beras non organik secara parsial memberi pengaruh yang signifikan terhadap keputusan pembelian beras non organik di Kota Salatiga.
Hal ini sesuai dengan pendapat Sumarwan et al. (2013) yang berpendapat bahwa ketersediaan produk/ merek beras di toko terdekat menjadi salah satu faktor penting bagi responden dalam menentukan keputusan pembeliannya.

Nilai signifikansi untuk variabel harga beras non organik sebesar 0,654 $<0,05$ sehingga $\mathrm{H}_{0}$ diterima dan $\mathrm{H}_{1}$ ditolak, artinya variabel harga beras non organik secara parsial tidak memberi pengaruh yang signifikan terhadap keputusan pembelian beras non organik di Kota Salatiga, Hal itu tidak sesuai dengan pendapat Tjiptono (2008) yang menyatakan bahwa dalam mengambil keputusan pembelian, harga menjadi salah satu faktor penting. Harga dinilai juga seringkali berpengaruh terhadap keputusan pembelian. Untuk memutuskan pembelian, konsumen akan mencari tau terkait harga dari produk yang akan ia beli dan membeli produk yang harganya sesuai dengan manfaat yang ditawarkan.

\section{SIMPULAN}

Berdasarkan hasil penelitian dapat disimpulkan bahwa:

1. Konsumen beras di Kota Salatiga mempunyai sikap lebih positif pada beras non organik dibandingkan beras organik. Atribut beras yang paling mempengaruhi sikap konsumen terhadap pembelian beras organik dan non organik adalah harga lebih murah.

2. Faktor-faktor yang mempengaruhi keputusan pembelian di Kota Salatiga secara simultan (serempak) variabel adalah jenis kelamin, usia, pendapatan, jumlah anggota keluarga, ketersediaan beras non organik dan harga beras organik. Secara parsial, faktor-faktor yang mempengaruhi keputusan pembelian secara signifikan di Kota Salatiga adalah variabel pendapatan dan ketersediaan beras non organik, sedangkan variabel jenis kelamin, usia, jumlah anggota keluarga dan harga beras non organik tidak berpengaruh secara 
signifikan terhadap keputusan pembelian beras di Kota Salatiga.

\section{DAFTAR PUSTAKA}

Anggiasari, N. M., Y. Indriani dan T. Endaryanto. 2016. Sikap dan pengambilan keputusan pembelian sayuran organik oleh konsumen di Kota Bandar Lampung. JIIA. 4(4) : 391-397.

Budiyanto. 1994. Perilaku Konsumen. Edisi Keenam. Jilid 1. Binarupa Aksara, Jakarta.

Engel, J. F., R. D. Blackwell dan P. W. Miniard. 1994. Perilaku Konsumen. Jilid 1. Edisi ke Enam. Binarupa Aksara, Jakara.

Ghozali, I. 2005. Aplikasi Analisis Multivariate dengan Program SPSS. Badan Penerbit Universitas Diponegoro, Semarang.

Gujarati, D. N. 2004. Basic Econometrics, Fourth edition. McGraw-Hill Inc, Singapore.

Lestari, S. R. A. 2018. Faktor-Faktor yang Mempengaruhi Perilaku Konsumen dalam Keputusan Pembelian Beras di Kota Makassar. Skripsi. Program Sarjana Universitas Hasanuddin. Makassar.

Pusdatin (Pusat Data dan Sistem Informasi Pertanian). 2013, Buletin Konsumsi Pangan. Pusat Data dan Sistem Informasi Pertanian Jakarta. 4 (2): 8-18.

Putra, I. K. T. E., I. P. G. Sukaatmadja dan N. N. K. Yasa. 2016. Perilaku konsumen mengkonsumsi beras organik di Kota Denpasar berdasar theory of planned behavior. E-Jurnal Ekonomi dan Bisnis Universitas Udayana. 5(8): 2609-2638.

Rusma, J., M. Hubeis dan B. Suharjo. 2011. Kajian preferensi konsumen rumah tangga terhadap beras organik di wilayah Kota Bogor. J. Manajemen IKM. 6 (1) : 49-54.
Sabran, B. 2008. Prinsip-Prinsip Pemasaran Jilid 1. Erlangga, Jakarta.

Setiadi, N. 2003. Perilaku Konsumen (Konsep dan Implikasi untuk Strategi dan Penelitian Pemasaran). Prenada Media, Jakarta.

Setiawan, A., W. A. Zakaria dan Y. Indriani. 2016. Perilaku konsumen dalam pembelian beras organik produksi Kabupaten Pringsewu. JIIA. 4 (2): 192199.

Statistik Pertanian. 2016. Pusat Data dan Sistem Informasi Pertanian Kementerian Pertanian Republik Indonesia. Kementan, Jakarta.

Sulistyana, P., J. H. Mulyo dan Jamhari. 2014. Konsumsi beras organik pada tingkat rumah tangga di Kota Yogyakarta. J. Agroekonomi. 24 (1): 26-36.

Sumarwan, U., A. Noviandi dan Kibrandoko. 2013. Analisis proses keputusan pembelian, persepsi dan sikap konsumen terhadap beras organik di Jabotabek. J. Pangan. 22 (2): 333-344.

Teme, Y. V. 2006. Analisis Pola Konsumsi Jeruk Lokal dan Jeruk Impor di Kota Bogor (Kasus Jeruk Medan dan Jeruk Mandarin). Skripsi. Program Sarjana Institut Pertanian Bogor. Bogor.

Tjiptono, F. 2008. Strategi Pemasaran. Edisi Tiga. Andi, Yogyakarta.

Winawan, B. dan N. N. K. Yasa. 2014. Pengaruh penataan produk, jenis kelamin, dan daftar belanja terhadap keputusan pembelian tidak terencana (studi kasus pada konsumen ritel di Kota Denpasar). E-Jurnal Manajemen Universitas Udayana. 3 (7): 2133-2149.

Windani, I dan J. H. Mulyo. 2009. Preferensi Konsumen terhadap Beras Organik di Kota Yogyakarta. Tesis. Program Pasca Sarjana Universitas Gajah Mada. Yogyakarta. 